\title{
NOT SO NATURAL HISTORY: DEPICTING THE ANIMAL ROLE IN HUMAN HISTORIES
}

Elaine Mitchell

Palmyrene (Northern Bald Ibis), and Vestigia a ante diluvium (Cave hyena) are a pair of watercolour paintings, which I produced in 2018 during my third year in the Bachelor ofVisual Arts degree. In both works, I sought to explore how animals are seen and depicted in contexts such as natural history illustration, museum taxidermy dioramas, and as subjects of science. I found that entangled in each of those subjects were deeper, underlying questions about how cultural expectations of the natural world can shape our perspectives on truth and subjectivity.

This article will be in two halves: one for each of the two paintings that I will discuss. The first half is concerned with a narrative deep from the annals of science history and the place that animals occupy in human narratives, while the second will delve into the successes and failures of how science has depicted animals in natural history illustration specifically.

\section{ANIMALS IN HUMAN HISTORIES}

I want to begin the first half with a narrative that begins in Northern Yorkshire, England, in I821. Quarrymen in the valley of Kirkdale were working when they discovered a cave underneath the road, and upon investigation, found that the cave was filled with piles of old bones. Samples were sent away for identification and the results that came back were shocking. The bones did not belong to cows or other livestock, as had been expected, but to hyenas, and specifically a species of hyena larger and more ancient than those still alive in Africa today. Alongside the hyena bones were those of rabbits, mice and wild boars, but also those of elephants, hippopotamuses, rhinoceroses, bison, and deer. These were not the kind of animals that one expected to find in the middle of rural England in the 19th century.

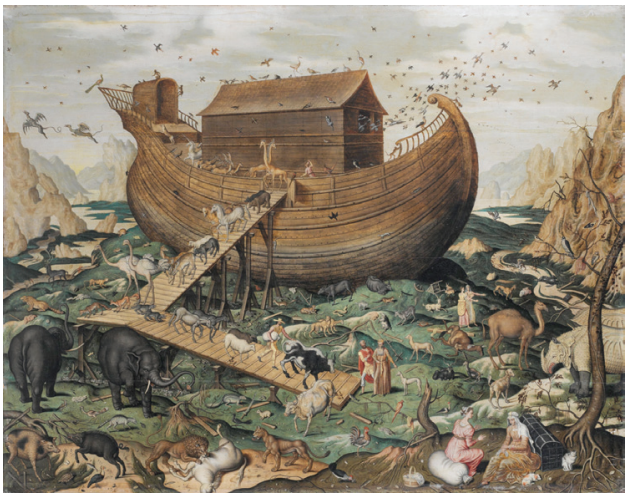

Figure I. Simon De Myle, Noah's ark on the Mount Ararat, 1570, oil on board, I14 × $142 \mathrm{~cm}$.
News of the discovery reached a man named William Buckland not long after it was made. Buckland was Oxford University's first professor in the still fledgling science of geology, and he was also an ordained minister of the Church of England; he would later go on to become the Dean of Westminster. As both a geologist and a religious man, Buckland was already caught in the middle of a contentious debate between the church and the scientific community, but his investigation of the Kirkdale cave, and the bones within it, would put him at the centre of that debate. The contentious question was this: how did the biblical flood fit into the story of earth's geological history? At this point in time, the flood was seen by many as a real, historical event, and many scientists were trying to use the new tools that geology presented them to search 
for evidence of the flood. They found evidence everywhere: the waters of the diluvial flood were given credit for carving out what we now know to be glacial valleys from the last ice age, and erratic boulders and loose stones once pushed by those same glaciers, were thought to have been cast into place by violent underwater currents. Importantly, fossils of dead and extinct animals were also attributed to the flood; was it not obvious that they were the remains of those animals and people not fortunate enough to make it on to the ark?

Buckland himself was a proponent of diluvian theory; he believed that the flood described in Genesis was a literal one. In his inaugural speech as geology professor he said:

"the grand fact of an universal deluge at no very remote period is proved on grounds so decisive and incontrovertible, that, had we never heard of such an event from Scripture, or any other, authority, Geology of itself must have called in the assistance of some such catastrophe, to explain the phenomena of diluvian action which are universally presented to us, and which are unintelligible without recourse to a deluge exerting its ravages at a period not more ancient than that announced in the Book of Genesis."

This is the context with which Buckland entered the Kirkdale cave. Diluvial theory said that the fossils there, those of elephant and hyenas and all the rest, had to have been carried from Africa to Britain and been deposited into the cave by turbulent flood waters. Buckland soon found that there was something lacking in this explanation though. The only entrance to the cave was small, too small for an elephant or rhinoceros to fit through, and it was low on the side of the cave rather than in the roof. ${ }^{3}$

Buckland also found tooth marks gouged into many of the bones, and there was extensive evidence that the hyenas had lived in the cave before their death; they had not been dead upon arrival like diluvial theory would posit. In the face of the evidence, Buckland developed a new theory. He concluded that the animals must have belonged to an ancient ecosystem from a time in the deep past when Britain was made up of hot savannas rather than rainy forests, and was more like modern-day Africa than the contemporary place.

To Buckland it seemed clear that the hyenas had belonged to the pre-diluvian world, and it was the flood that had caused the environment and ecosystem to change. The hyenas themselves had not been killed by the forty days and forty nights of rain but the world as they knew it had.

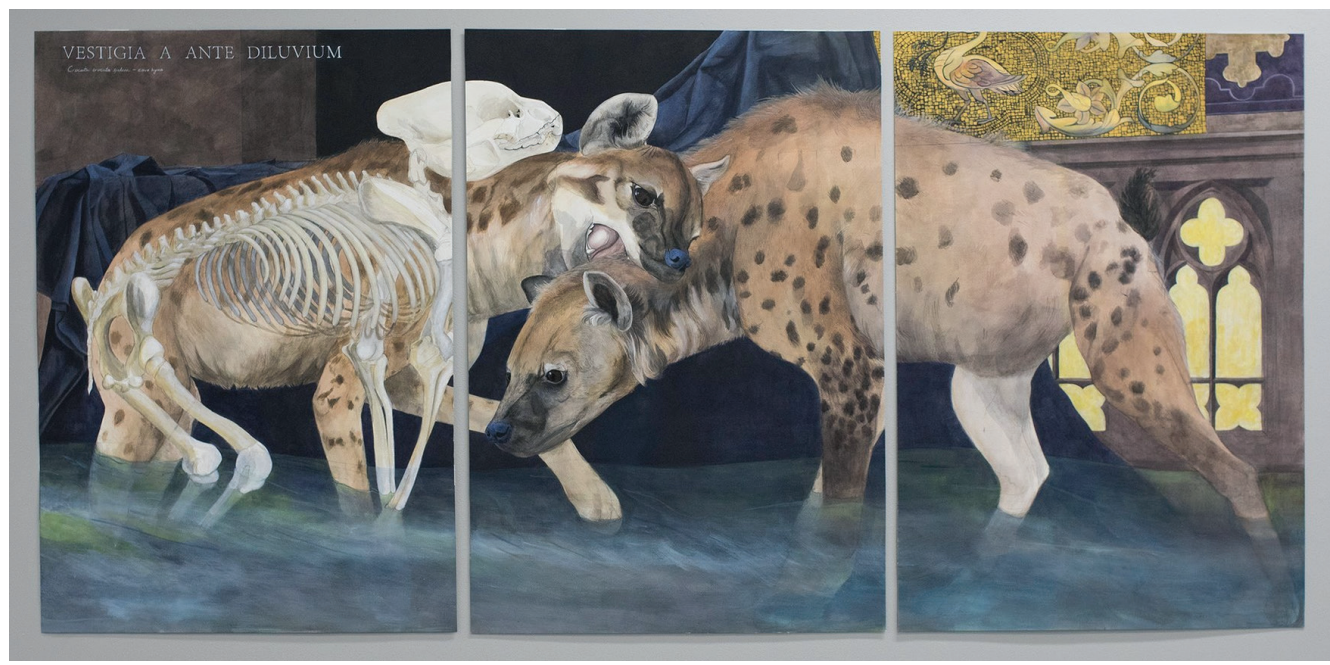

Figure 2. Elaine Mitchell, Vestigia A Ante Diluvium (Cave Hyena), 20I8, watercolour, acrylic, and gouache on paper, $196 \times 95 \mathrm{~cm}$. 
Buckland believed this version of events for years, but a slow shift occurred and as time progressed, the presence of the flood in his hyena story fades. By 1840, 19 years after the cave was first found, Buckland saw the story not as proof of the flood, but as a puzzle piece that fit into the new, up-and-coming theory of universal glaciation, or the ice age. This version of the story is much closer to what we believe today. The hyenas and their contemporaries had lived in the second to last interglacial period of the last ice age, which in England is called the Ipswichian interglacial.

My goal with Vestigia a ante diuluvium (2018) was not to illustrate the narrative of the Kirkdale cave, but to use its story as a basis through which I could engage with its contextualising themes. The painting is a triptych on paper and depicts three (or perhaps two and half) life-sized cave hyenas. I used measurements taken from their closest relative, the spotted hyena, and scaled them up to match the size of a cave hyena, as based on skeletal and fossil remains.

I imagined the hyenas caught in flux, in the moment of change as they shifted from being living breathing creatures, to symbols within a human narrative that would forever be fixed in history. On top of that, I wanted to instil a sense of theatricality or artificiality into the painting in reference to the staged and often odd poses you see in museum taxidermy dioramas and in natural history illustrations. The painting's connection to museum displays is also why the painting is split over three panels. The negative space of the splits was intended to mimic the shape of the cabinetry that traditionally houses museum dioramas. They present a barrier between the human viewer and the animals viewed; the hyenas are stuck inside the picture frame, while the viewer is stuck outside of it.

\section{ANIMALS IN NATURAL HISTORY ILLUSTRATION}

Palmyrene is about a narrative from history just as Vestigia is, but instead of exploring narrative context, here I wanted to consider the broader context of how animals, and specifically birds, are represented in natural history illustration. Both paintings are intended to be historiographical rather than historical; they consider how a history is told and represented, rather than focusing on the contents of the history itself.

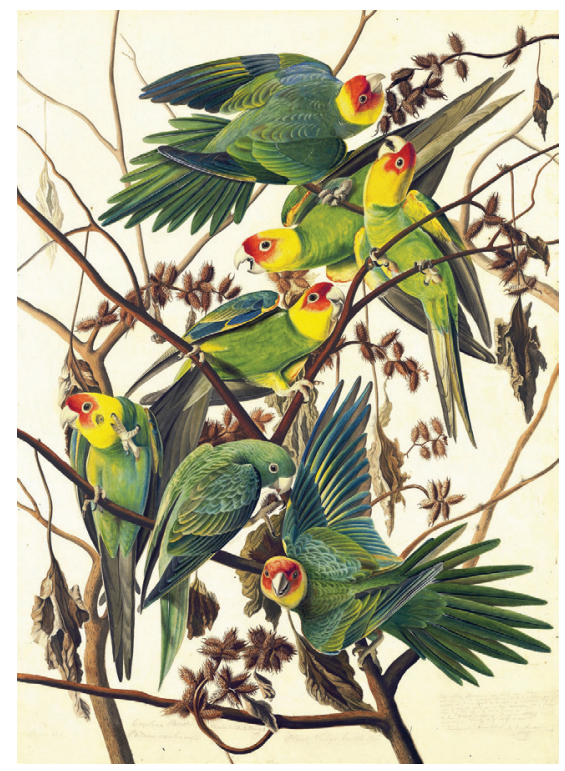

Figure 3. John James Audubon, Plate 26 (Carolina Parakeets), 1833, coloured engraving
Natural history illustration is both an art and a science, which aims to convey biological information in an accurate, intelligible way. It is a field which formed in the era before photography and the other indexical media that we have now, in a time when it would take months for messages to travel between continents, and when language barriers made it harder for scientists in different countries to share their discoveries. For natural history illustration to be able fulfil its goal as an information source, it had to adopt a set of stringent conventions. Natural history illustrations had to be realistic and comprehensive in their depiction of any given species, and often illustrators would work from taxidermy and skins to ensure this. Individual animals within an illustration would be posed in such a way that all of their identifying physical features were visible to the viewer, and if the species displayed any sex- or age-based variation in size or colour, then often multiple individuals would be arranged together so that all the different variations were represented.

In Plate 26 (Carolina Parakeets), from John James Audubon's The Birds of America ${ }^{4}$, Audubon has depicted multiple birds within one illustration, as is common in natural history 
illustrations of small animals. The illustration displays a consistent internal scale and perspective, and the animals are flatly lit so there are no shadows that might confuse their forms or markings. In the background of Plate 26, there is only a limited representation of setting, and this too is common among natural history illustrations. In this case, the setting is a cocklebur plant that serves to ground the parakeet figures within the illustration, so that they are not left floating in the middle of blank space.

There are many things which Plate 26 does very well, and, as a tool intended to convey physical information about the species, it succeeds. You can count the number of feathers that make up the species' tails and wings, as well as see how those body parts fold and fan. The multiplicity of poses lets a viewer turn the bird around in their head to see its plumage from every angle, its beak both open and closed, and feet both relaxed and grasping. There are limitations to what Plate 26 can tell us about the species though.

Because Audubon has given the representation of physical information such high priority in this illustration, behavioural information has been distorted. To see this, one only has to look at each parakeet individually and imagine the strain that its muscles must be under to hold its pose. Their necks are craned, and their wings have been pulled away from their bodies while only half open. Only two of the seven are perched upright; the others hang off the cocklebur plant sideways toward the viewer so that they are easier to see.

The parakeets do not pose as real, living birds might, because they aren't living. Audubon worked from taxidermy specimens that would have been contorted into reference poses for him to draw from. In Paper Nature: 500 years of animal art (2016), Charlotte Sleigh writes: "An image could stand in for a specimen for the purposes of description and identification. Even a drawing could be substituted for a specimen which would fade, wilt, or crumble when sent from one city to another, or from one continent to another." From this I think it is clear to see that natural history illustration isn't intended to represent living animals; it is instead a more portable and convenient type of taxidermy that studies the dead in the hope of learning about the living.



Figure 4. Elaine Mitchell, Palmyrene (Northern Bald Ibis), 20 I 8, watercolour, acrylic, and gouache on paper, I32 × $195 \mathrm{~cm}$. 
The relationship of natural history illustration to the animals it depicts was something I thought about constantly while working on Vestigia and Palmyrene. I considered making work where the animals were ostensibly dead and looked it, rather than shrouded by a veneer of life as traditional natural history illustration is. I also thought about how natural history illustration would look if it was drawn from living subjects, and it is this latter idea that Palmyrene engages with.

Palmyrene depicts two of the critically endangered Northern bald ibis, at life-size over two sheets of paper. I imagined the painting not as a mock illustration, but as an illustration of the illustration process; the subject is not the species itself, but how it has been depicted. I then considered what would change about the composition if the ibises depicted were still alive, unlike Audubon's dead parakeets, and not fully cooperating with the illustrator.

In this scenario, the ibises had been posed as the parakeets had been, with outstretched wings, craned necks, and fanned tails. But in the moment before the illustration could be made, the explosions erupted in the background and the ibises were frightened instantly out of their poses and we see them as they are turning to flee. Like the hyenas in Vestigia, the animals are in a moment of change, but this time it is in the opposite direction; they are going from being representations of their species, back to being living individuals.

Elaine Mitchell graduated from the Dunedin School of Art in 2019 with a first class honours degree in Visual Arts. She is interested in how human culture represents the natural world and in stories where the two realms overlap.

I William Buckland, "XVI. Account of an Assemblage of Fossil Teeth and Bones of Elephant, Rhinoceros, Hippopotamus, Bear, Tiger, and Hyæna, and Sixteen Other Animals; Discovered in a Cave at Kirkdale, Yorkshire, in the Year I 82 I: with a Comparative View of Five Similar Caverns in Various Parts of England, and Others on the Continent," Philosophical Transactions of the Royal Society of London, I 12 ( I 822): I7|-236. https://doi.org/ I 0. I098/rstl. I 822.00 I7.

2 William Buckland, Vindiciæ Geologicæ: the Connexion of Geology with Religion, Explained in an Inaugural Lecture Delivered before University of Oxford, May 15, 1819, on the Endowment of Readership in Geology (Oxford: University Press, 1 820), https://archive. org/details/b22393304/mode/2up)

3 William Buckland, "XVI. Account of an Assemblage of Fossil Teeth and Bones..."

4 John James Audubon, The Birds of America (New York: J B Chavalier, 1840). https://www.biodiversitylibrary.org/ bibliography/6141 |\#/summary.

5 Charlotte Sleigh, The Paper Zoo: 500 Years of Animals in Art (Chicago, IL:The University of Chicago Press, 2017$), 12$. 